\title{
Responsabilidad por incumplimiento del deber de información del abogado*
} Responsibility ensuing from non-compliance with a lawyer's duty to inform their client

\section{Sebastián Bozzo Hauri** Gonzalo Ruz Lártiga***}

\section{RESUMEN}

Este trabajo se circunscribe al ordenamiento jurídico chileno. Se abordará especificamente la obligación de información que le cabe al abogado una vez perfeccionada la relación contractual con el cliente. Para esto, se dilucidará el fundamento de este deber, las caracteristicas que tiene esta obligación en relación con su contenido y oportunidad, y se definirá cuáles serian las consecuencias de su incumplimiento.

\section{PALABRAS CLAVE}

Deber de información, abogado, responsabilidad civil, incumplimiento-daño.

\begin{abstract}
The present paper describes the Chilean legal system, specifically in relation to a lawyer's obligation to keep their client informed once the contractual relationship has been entered into.

It will elucidate the basis of this duty and the characteristics of this obligation in relation to its content and the opportunity it represents, and will, moreover, define the consequences of non-compliance.
\end{abstract}

\section{KEY WORDS}

Right to information, lawyer, civil liability, non-compliance, damages.

\footnotetext{
* Artículo de investigación. Recibido el 27 de septiembre de 2018 y aceptado para su publicación el 23 de mayo de 2019. Este trabajo se enmarca en el proyecto de investigación DIUA107-2017 de la Vicerrectoria de Investigación y Postgrado de la Universidad Autónoma de Chile.

** Decano de la Facultad de Derecho de la Universidad Autónoma de Chile. (sebastian.bozzo@uautonoma.cl) orcid.org/0000-0001-9468-4594

*** Profesor investigador en el Instituto de Investigación en Derecho de la Universidad Autónoma de Chile. (gonzalo_ruz@yahoo.fr) orcid.org/0000-0001-5631-471X
} 


\section{SUMARIO}

1. Introducción

2. Fundamentos del deber de informar del abogado en la fase de ejecución del contrato

3. Fundamentos del deber de informar del abogado después de terminado el contrato

4. Sobre la oportunidad y contenido de la información

5. Requisitos de la información

6. Responsabilidad por el incumplimiento del deber de informar

7. Conclusiones

\section{Introducción}

El oficio de abogado nace en el contexto de las relaciones sociales, ante la necesidad de que cada uno tenga y disfrute pacíficamente de lo suyo, ya sean bienes o derechos. Por ello, como afirman sociólogos y juristas, su aportación es imprescindible para la realización de la justicia y, en definitiva, para la paz social. En la actualidad, difícilmente se pueden concebir las sociedades occidentales sin la figura del abogado profesional. ${ }^{1}$ De ahí la importancia de estudiar las consecuencias dañosas que se pueden originar del ejercicio profesional de los abogados. En especial, es necesario profundizar en la relación que este tiene con su cliente, centrándose en el deber de información que le cabe al letrado y las consecuencias por su incumplimiento.

El cumplimiento del deber de información resulta trascendental para mantener un equilibrio en la relación entre abogado y cliente, debido al problema de asimetría de información y al problema de racionalidad limitada. Estos dos problemas son muy comunes en el ámbito de los servicios profesionales, pues, por lo general, el cliente no tiene el conocimiento específico para determinar o negociar las condiciones del contrato que celebra con el profesional (problema de asimetría de información). A su vez, el cliente no tiene la capacidad de procesar de forma adecuada la información que le entrega el profesional, lo cual le impide valorar si lo que le recomienda el profesional es idóneo para la situación que consulta (problema de racionalidad limitada).

\footnotetext{
1 Aparisi Miralles, Isabel, Deontología profesional del abogado, Valencia, Tirant lo Blanch, 2013, p. 25. En el mismo sentido, Alain Lévy expresa que "la profesión de abogado, asi como la del médico [...] ocupa en la sociedad una posición particular por dos razones. Por una parte, la defensa de los derechos de los justiciables es un componente esencial del Estado de derecho. Por otra parte, como auxiliar de la justicia, el abogado está en relación con terceros cuyos intereses son protegidos, particularmente, las contrapartes, los otros abogados, los jueces y el mismo Estado". Lévy, Alain B., "Le devoir d'information de l'avocat", Anwalts Revue de L'avocat, núm. 6, vol. 7, p. 265.
} 
Por otra parte, como analizaremos más adelante, se debe considerar la particular relación del cliente y el abogado. ${ }^{2}$ Conforme indica el artículo 2118 del Código Civil chileno, esta se rige por las reglas del mandato, contrato que se caracteriza por la confianza, y que es determinante para la elección del mandatario. En este sentido, el cliente elige a su contraparte porque cree que es la persona idónea para que le represente, pensando en que resguardará sus intereses. El abogado supuestamente velará por defenderle para que quede indemne u obtenga los beneficios esperados. En virtud de esto último, el abogado debe suministrar información a su cliente cada vez que sea relevante y determinante para el desarrollo del encargo. Por ello, quien debe valorar la entrega de información es precisamente el profesional, ${ }^{3}$ para que, así, el cliente pueda tomar las decisiones que tengan una repercusión jurídica o económica de relevancia.

En Chile, al abogado no le asiste legalmente el deber de informar, como sí ocurre en el ámbito de la responsabilidad médica, donde, por ley, ${ }^{4}$ se establece el deber del médico de informar al paciente. Para ello, se indica que la información entregada debe ser oportuna y comprensible, y que el contenido de dicha información debe ser definido.

En el caso del abogado, la exigencia de informar para la correcta formación del consentimiento, la ejecución y la finalización del contrato, se circunscribe a las reglas del derecho común. Por lo tanto, este deber de informar suele supeditarse, en contenido, forma y extensión, a las reglas generales del derecho como fuente primera y a las normas profesionales (lex artis) y deontológicas ${ }^{5}$

\footnotetext{
${ }^{2}$ Los abogados además tienen un verdadero monopolio de la defensa ante los tribunales de justicia que justifica esta obligación de informar. El artículo 520 del Código Orgánico de Tribunales señala: "Los abogados son personas revestidas por la autoridad competente de la facultad de defender ante los Tribunales de Justicia los derechos de las partes litigantes". Por ello, el artículo 1 de la Ley 18.120 dispone que "La primera presentación de cada parte o interesado [...] deberá ser patrocinada por un abogado habilitado para el ejercicio de la profesión [...] El abogado conservará este patrocinio y su responsabilidad, mientras en el proceso no haya testimonio de la cesación de dicho patrocinio. Podrá, además, tomar la representación de su patrocinado en cualquiera de las actuaciones, gestiones o trámites de las diversas instancias del juicio o asunto".

${ }^{3}$ Asi lo expresan, entre otros, Crespo Mora, Maria Carmen, La responsabilidad del abogado en el derecho civil, Madrid, Civitas, 2005, p. 182, y Gómez CAlle, Esther, Los deberes precontractuales de información, Madrid, La Ley, 1994, pp. 87 y ss.

${ }^{4}$ Ley 20.585, de 2013 la cual señala: "Toda persona tiene derecho a ser informada, en forma oportuna y comprensible, por parte del médico u otro profesional tratante, acerca del estado de su salud, del posible diagnóstico de su enfermedad, de las alternativas de tratamiento disponibles para su recuperación y de los riesgos que ello pueda representar, así como del pronóstico esperado, y del proceso previsible del postoperatorio, de acuerdo con su edad y condición personal y emocional".

${ }^{5}$ Gutmann sostiene que "la obligación deontológica no puede ser calificada, de forma sistemática, como obligación moral o jurídica. Una aproximación menos drástica se impone, teniendo en cuenta, tanto el grado de elaboración estructural del sistema donde ésta se inserta, como de los objetivos sustanciales que ella persigue". Gutmann, Daniel, "L'obligation déontologique entre l'obligation morale et l'obligation juridique", Archives de Philosophie du Droit, núm. 44, p. 115.
} 
como segunda fuente. Excepcionalmente, conforme a la Ley 19.496 sobre protección de los derechos de los consumidores, cuando sea posible considerar que la prestación de servicios jurídicos es otorgada por un proveedor, será posible aplicar esta legislación en relación con este deber.

De tal forma, en este trabajo abordaremos, por una parte, los fundamentos del deber de informar del abogado, en las distintas etapas del iter contractual, analizando la oportunidad y contenido de la obligación, además de sus requisitos, para, finalmente, analizar las consecuencias de su incumplimiento.

\section{Fundamentos del deber de informar del abogado en la fase de ejecución del contrato ${ }^{6}$}

Una vez celebrado el contrato, será importante considerar qué papel desempeña la información que debe entregar el abogado a su cliente. No será lo mismo si este deber de información se debe suministrar como una obligación principal -en el marco del contrato que se suscribe entre letrado y cliente- o si este deber de información constituye una obligación accesoria de dicho contrato. ${ }^{7}$

Por un lado, la información puede fungir como objeto del contrato. Si la información constituye la información principal y exclusiva del contrato, el fundamento de tal obligación ha de ubicarse en el artículo 1545 del Código Civil chileno. Es decir, el fundamento del deber se encuentra en la ley del contrato.

Por otro lado, la información puede ser un deber accesorio del contrato. Cuando el deber de información se configura como un deber accesorio del contrato, se pueden presentar diferentes hipótesis.

Primera, las partes, en virtud del principio de la autonomía de la voluntad, pueden haber regulado en el contrato este deber de información, aunque es una cuestión muy poco probable.

Segunda, en el caso de que las partes no hubiesen establecido nada, es posible entender que existe igualmente este deber de información. Esto es así en el entendido de que el contrato entre abogado y cliente se sitúa bajo el régimen contractual del mandato por aplicación del artículo 2118 del Código Civil, el cual establece: "Los servicios de las profesiones y carreras que suponen largos estudios, o a que está unida la facultad de representar y obligar a otra persona respecto de terceros, se sujetan a las reglas del mandato". Y por el artículo 2155 del mismo código, que señala: "El mandatario es obligado a dar cuenta de su

\footnotetext{
${ }^{6}$ Sobre el fundamento del deber de informar en la etapa de formación del contrato, véase el trabajo que se publicará en revista lus et Praxis de la Universidad de Talca, Chile.

7 De Ángel YÁgüez, Ricardo, "Responsabilidad por informar", en Juan Antonio Moreno Martínez, Perfiles de la responsabilidad civil, Madrid, Dykinson, 2000, p. 183.
} 
administración”. En virtud de estas dos disposiciones, sería posible deducir que, aunque el deber de información no sea una obligación principal del contrato -por entenderse que son las reglas del mandato las que se aplican en la relación entre abogado y cliente-, existe de igual manera la necesidad de informar, toda vez que el mandatario es obligado a dar cuenta de su administración. ${ }^{8}$

Tercera, se puede también justificar este deber de información en el artículo 1546 del Código Civil chileno, que obliga a las partes a ejecutar los contratos de buena fe y, por consiguiente, obligan no solo a lo que en ellos se expresa, sino a todas las cosas que emanan de la naturaleza de la obligación o que, por la ley o la costumbre, pertenecen a ella.

Cuarta, durante la ejecución del contrato, es posible aplicar la normativa relativa a la Ley 19.496 sobre protección de los derechos de los consumidores artículo $3 \mathrm{~b}$ ). En este sentido, siempre que exista un proveedor y consumidor conforme a dicha ley, existirá la obligación legal del abogado de informar de todas aquellas cuestiones relevantes del servicio que se presta, para permitir al consumidor o usuario decidir sobre aquellas cuestiones que podrían acarrarle un mayor costo económico en la tramitación del proceso. ${ }^{9}$ El artículo 3 b) de la ley de protección al consumidor en Chile indica que el consumidor tiene "El derecho a una información veraz y oportuna sobre los bienes y servicios ofrecidos, su precio, condiciones de contratación y otras características relevantes del mismo, y el deber de informarse responsablemente de ellos".

\footnotetext{
${ }^{8}$ En España, lo conciben de esta manera algunos autores como Cervilla Garzón, Maria Dolores, La prestación de servicios profesionales, Valencia, Tirant Lo Blanch, 2001, p. 26. Sin embargo, como bien señala, esta opción presenta ciertos inconvenientes. En primer lugar, porque, al igual que en España, en Chile se utiliza la frase "dar cuenta", lo cual podría interpretarse como la mera presentación de un balance contable de la labor desempeñada. Además, es posible entender que la rendición de cuentas se debe realizar al momento de finalizar la gestión encomendada y no durante la ejecución del contrato. Crespo Mora, Maria CARMEN, La responsabilidad del abogado en el derecho civil, Madrid, Civitas, 2005, p. 161.

${ }^{9}$ En el derecho comparado se puede ver esta misma posición. En España, autores como Cervilla Garzón, María Dolores, "Responsabilidad del abogado por incumplimiento de la obligación de información. Comentario a la sts de 14 de mayo de 1999 (RJ 1999, 3106)", Revista de Derecho Patrimonial, núm. 5, p. 283, o Pérez Garcia, Pedro Antonio, La información en la contratación privada. En torno al deber de informar en la Ley General para la Defensa de los Consumidores y Usuarios, Madrid, Instituto Nacional del Consumo, p. 309, entienden que es aplicable la Ley 26/1984, de 19 de julio, General para la Defensa de Consumidores y Usuarios, en concreto, del artículo 13.1, con la correspondiente adaptación a la prestación de servicios. Este precepto desarrolla uno de los derechos básicos de los consumidores enumerados por el artículo 2.1, cuyo apartado d) consagra el derecho a la "información correcta sobre los diferentes productos o servicios y la educación y divulgación para facilitar el conocimiento sobre su adecuado uso, consumo o disfrute". Estos autores entienden que, cuando el abogado contrate directamente con consumidores y usuarios, se podrán aplicar dichos preceptos. María Dolores Cervilla, además, postula la posibilidad de que dicha normativa se aplique también por analogía, incluso cuando el cliente no sea un consumidor; esto sin mucho apoyo. Por su parte, en Francia, se puede constatar la existencia de una imposición hacia los prestadores de servicio en el sentido del deber de informar. De esta forma, el artículo 2 de la ley francesa 92-60, de 18 de enero de 1992 (convertido en el artículo L111-1 del Code de la Consommation) dispone: "Tout professionnel vendeur de biens ou prestataire de services doit, avant la conclusion du contrat, mettre le consommateur en mesure de connaitre les caractéristiques essentielles du bien ou du service".
} 


\section{Fundamentos del deber de informar del abogado después de terminado el contrato}

Además, para el letrado existe la obligación de informar a su cliente incluso una vez se ha finalizado el encargo. El fundamento de este deber se puede encontrar en el principio general de la buena fe, como elemento integrador del contenido normativo del contrato.

Este tipo de contrato de prestación de servicios, por regla general, es de intuitu personae. Por ello, al abogado le corresponde cumplir con un deber de fidelidad mínimo, para que, con la información recibida, su cliente evite aquellas consecuencias que puedan producir un menoscabo en su situación personal o estado patrimonial.

Para ilustrar la importancia de lo anterior, sirve de referencia una de las primeras sentencias que trató la obligación de informar del abogado en España, relativa a la ruptura unilateral del contrato por parte del profesional..$^{10}$ La resolución, en su fundamento de derecho segundo, señala: "Incursos en el deber de fidelidad se hallan, en relación con el contrato con abogado en el caso de autos, primero, el deber de información adecuada durante la vigencia de la relación contractual y también con mayor fuerza, el momento de la extinción".

Esta sentencia diseña una obligación de informar cuyo contenido y alcance es muy similar a la obligación de información de los médicos, y exige a los abogados informar inclusive después de finalizado el contrato.

\footnotetext{
${ }^{10}$ STS de 14 de mayo de 1999 (RJ 1999/3106). En esta sentencia, el Tribunal Supremo español resuelve acerca de la negligencia de un abogado que debe emprender acciones penales por el fallecimiento del hijo de sus clientes, en una piscina municipal. El Juzgado de Instrucción dictó sobreseimiento. El abogado notificó este hecho a sus clientes, pero sin hacerles saber que disponian de la vía civil. Cuando los clientes volvieron a comunicarse con el abogado, ya había transcurrido el plazo de un año para el ejercicio de la acción civil. El Tribunal Supremo sostuvo: "Pues bien, aun cuando no constase que el citado letrado hubiese asumido una obligación genérica de defender los intereses del matrimonio actor en toda clase de procedimientos al haber sido designado en un apoderamiento apud acta en punto a la defensa en las concretas diligencias penales en que decidieron personarse, no cabe duda alguna de que en la carta que les dirigió en la fecha 6 de febrero, no debió haberse limitado a aconsejar que no merecía la pena recurrir el auto de sobreseimiento de las referidas actuaciones penales, en cuanto que en buena técnica jurídica y en cumplimiento del deber de confianza que en él habían depositado sus clientes y a tenor de las diligencias correspondientes al buen padre de familia que impone el artículo $1104 \mathrm{del} c c$, tendría que haber extendido el consejo a las posibilidades de defensa de una reclamación en el orden civil por culpa contractual o extracontractual, y a la conveniencia de mantener una entrevista inmediata con el matrimonio para explicarle con detalle el alcance y significado de tales posibilidades, proceder el así indicado que, indudablemente, se habría acomodado al correcto y normal cumplimiento de las obligaciones deontológicas inherentes al ejercicio de la abogacía rectamente entendidas, y sin que sea factible exculpar el proceder enjuiciado por las circunstancias de que los clientes no hubiesen solicitado al señor letrado les informase acerca de otras posibilidades de satisfacer sus pretensiones y de que en una entrevista celebrada en fecha muy posterior carecen de relevancia respecto a desvirtuar la omisión inicial en que incurrió en la carta de referencia".
} 
La obligación de información no se agota, sino que subsiste mientras dure la relación entre las partes, y puede extenderse, incluso, a momentos posteriores a la finalización de la relación. Cervilla Garzón indica que esta situación es frecuente, pues, cuando se extingue el contrato de prestación de servicios -bien porque el facere para el que fue contratado ha sido realizado, bien por desistimiento unilateral de cualquiera de las partes, o por otra causa-, es cuando la obligación de información puede cobrar especial importancia. ${ }^{11}$

\section{Sobre la oportunidad y contenido de la información}

$\mathrm{Al}$ abogado le corresponde la obligación de informar antes de la celebración del contrato con su cliente y durante la ejecución del contrato. Crespo Mora ${ }^{12}$ y diferentes sentencias del Tribunal Supremo español ${ }^{13}$ mencionan que también existiría la obligación de informar una vez extinguida la relación contractual. Otra cosa es que el abogado no cumpla con las prestaciones propias del contrato, ya sea por no entregar el informe en derecho (obligación principal) o por no informar de los resultados del juicio una vez finalizado el pleito en que representaba a su cliente (obligación accesoria). Siempre se debería entender que la obligación de informar se enmarca en las prestaciones propias del contrato.

\section{a) Información de carácter precontractual}

$\mathrm{Al}$ abogado le corresponde la obligación de informar antes de que se perfeccione el contrato entre él y su cliente. Esta información es esencial para que el destinatario de la oferta pueda consentir de manera informada (consentimiento informado). Conforme señala Ortí Vallejo, ${ }^{14}$ esta información se puede clasificar en dos grupos. El primero refiere a la relación con aquellas informaciones sobre las condiciones jurídicas de contratación del servicio, cuestiones que atienden a los honorarios del profesional, plazos de pago, cantidades a cuenta para la tramitación del juicio, entre otras. El segundo grupo atiende a informaciones respecto a la prestación objeto del contrato, como las posibilidades de éxito

\footnotetext{
${ }^{11}$ Cervilla Garzón, Maria Dolores, "Responsabilidad del abogado por incumplimiento de la obligación de información. Comentario a la sts de 14 de mayo de 1999 (RJ 1999, 3106)", Revista de Derecho Patrimonial, núm. 5, p. 284.

${ }^{12}$ Crespo Mora, Maria Carmen, "La responsabilidad civil del abogado en el derecho español: perspectiva jurisprudencia", Revista de Derecho, núm. 25, p. 266.

${ }^{13}$ En España, así lo reconoce al menos la sts de 25 de marzo de 1998, según la cual: "inmersos en el deber de fidelidad se hallan, en relación con el contrato [...] primero, el deber de información adecuada durante la vigencia de la relación contractual y también, con mayor fuerza, en el momento de la extinción".

${ }^{14}$ Orti Vallejo Antonio, "Comentario al artículo 13.1 LGDCU", Comentarios a la Ley General para la Defensa de los Consumidores y Usuarios, Rodrigo Bercovitz, Javier Salas y Alberto Bercovitz (coords.), Madrid, Civitas, 1992, p. 414.
} 
de una determinada acción o recurso; ventajas o inconvenientes de seguir un determinado procedimiento, etcétera. De esta manera, el abogado debe informar a su cliente, por ejemplo, sobre la decisión de recurrir a resoluciones importantes dentro del proceso, que pueden significar importantes costos para el representado o, contrario sensu, cuando el abogado determina no recurrir a una resolución sin consultar a su cliente.

Por otra parte, cada vez que el contrato entre abogado y cliente se celebre en torno a la persona del abogado, es decir que tenga el carácter intuitu personae, el abogado deberá informar todas aquellas cuestiones relativas que afecten a sus propias cualidades, antes de contratar. ${ }^{15}$ Es lógico que, si se consideraron las características personales del abogado, antes del acuerdo, este informe de los impedimentos que puedan surgir. De tal modo, será posible determinar si el abogado puede llevar personalmente las diligencias del juicio para el cual fue contratado. ${ }^{16}$

Asimismo, se considera como información indispensable aquella relativa al precio y la fijación de los honorarios; ello debe ser del conocimiento del cliente para que este pueda decidir sobre la contratación del letrado. Aunque en ciertas ocasiones no es posible definir un precio exacto - por las características propias del servicio que presta el abogado-, ello no exime de la obligación de entregar un importe aproximado o las bases para su determinación. ${ }^{17}$

Además, creemos que será necesario que el abogado informe sobre los costos del proceso. Si bien esto no se puede comprender dentro de los honorarios, para el cliente tiene una repercusión directa en el costo que conlleva la contratación y, por ende, la determinación de contratar o no.

De lo expuesto, se puede infringir el deber de informar en esta fase, ya sea por un comportamiento activo, por comunicar al cliente una información falsa $o$ engañosa, o a través de un comportamiento pasivo, por guardar silencio sobre aspectos que debiese conocer el cliente antes de contratar.

El Código chileno de Ética Profesional del Colegio de Abogados, del año 2011, reconoce el deber de información precontractual que corresponde al letrado. En su artículo 28, indica que "El abogado debe informar sobre los riesgos y alternativas de acción de modo que el cliente se encuentre en condiciones de evaluarlos sin hacerse falsas expectativas”. De esta forma, el código se preocupa de que el cliente conozca las posibilidades de éxito de la cuestión que pretende encargar

\footnotetext{
${ }^{15}$ Crespo Mora, Maria Carmen, La responsabilidad del abogado en el derecho civil, Madrid, Civitas, 2005, p. 170.

${ }^{16}$ Gómez Calle, Esther, Los deberes precontractuales de información, Madrid, La Ley, 1994, pp. 102-103.

${ }^{17}$ Albaladejo Garcia, Manuel, Derecho civil. Derecho de obligaciones, tomo 2, Barcelona, Bosch, 1989, p. 302. El Código Deontológico de la abogacía española, en su artículo 13.9 b), limita la información del abogado al importe aproximado, en cuanto sea posible, de los honorarios o de las bases para su determinación.
} 
al profesional, y de que, así, pueda tomar una decisión sobre la conveniencia de contratar o no. De una u otra forma, lo que busca el precepto es que el cliente consienta de manera informada.

Sobre la necesidad de informar el valor de sus honorarios, el código del ramo no fija una oportunidad en que debe el profesional comunicarlo. El artículo 34, al regular la forma y oportunidad para convenir los honorarios, señala: "Encargado un asunto profesional, el abogado procurará acordar los honorarios a la brevedad posible". El artículo no determina que el precio deba informarse necesariamente antes de asumir el encargo, sino que, por el contrario, da a entender que el abogado podrá asumir el encargo y dentro de un periodo que el propio profesional determine, acordará el monto con el cliente.

Si bien el precepto se refiere a convenir el precio, de modo que el valor de los honorarios pueda ser aceptado por el cliente previamente, en la práctica, se deja al abogado en una posición dominante respecto del cliente. Si el cliente entregó el encargo al letrado y, transcurrido un lapso, este último determina fijar un valor, puede dejar al cliente con las manos atadas y obligado a aceptar la propuesta de precio. Hubiera sido mejor que el código estableciera una obligación clara y precisa de comunicar los honorarios antes de recibir un encargo, y no una vez recibido. Ahora bien, cabe precisar que este código es deontológico y, por lo mismo, solo tiene aplicación para aquellos abogados que libre y voluntariamente se afilian al Colegio; por ende, quedan sometidos a su jurisdicción disciplinaria.

\section{b) Como deber contractual}

La obligación de informar puede ser la obligación principal del contrato o una prestación accesoria. En el caso de ser una obligación principal, el contenido de la información entregada por el letrado deberá cumplir con los requisitos o características que permitan satisfacer la necesidad del cliente. En este sentido, si la obligación es la redacción de un informe en derecho para entregar una opinión jurídica sobre algún asunto que le permita tomar una decisión, dicho informe deberá reunir ciertas cualidades para que el cliente pueda resolver el problema o negocio que enfrenta.

Si la entrega de información es un deber impuesto al abogado por el contrato, la omisión, prestación defectuosa de la información, así como la transgresión del encargo recibido, podrán ser una fuente de responsabilidad civil del abogado, cuando de ello deriven consecuencias perjudiciales para el cliente. ${ }^{18}$ Se estará entonces ante la responsabilidad por informar, la cual, según De Ángel

\footnotetext{
${ }^{18}$ Crespo Mora, Maria Carmen, La responsabilidad del abogado en el derecho civil, Madrid, Civitas, 2005, p. 142.
} 
Yagüez, ${ }^{19}$ se define como aquella "en que se puede incurrir por dar a otro -0 en su caso por no dar- informaciones que luego causan algún 'perjuicio' a quien las recibe".

Como sabemos, para exigir la responsabilidad civil, deben concurrir los requisitos propios de la responsabilidad, pues la información puede ser equivocada, pero aun así no concurren los presupuestos del deber de responder.

En el caso de que la obligación de informar se considere un deber accesorio, la oportunidad de la entrega de dicha información debe darse cada vez que sea necesario para el buen desarrollo del encargo que se le entregó al abogado. De esta forma, si en el transcurso de la ejecución del mandato existe un sobrecosto que no se consideró en un principio, se deberá informar al cliente para que evalúe las opciones de continuar o no.

Pero, además, la información debida puede referirse también a materias que, si bien están relacionadas, no constituyen estrictamente la prestación de servicio para el que fue contratado el letrado. En este sentido, aun cuando el abogado sea contratado para defender, por ejemplo, los intereses de sus clientes en la vía penal, deberá informar de la existencia de otras vías, como la civil. Asimismo, el plazo de ejercicio y factibilidad de utilizar dicha vía para reclamar una posible indemnización de perjuicio a la que pudiera tener derecho. No sería excusa el hecho de no informar porque el cliente no le ha solicitado información sobre otras opciones de reclamación. El abogado, como profesional del derecho, debe estar preparado para informar a su cliente de las diferentes opciones $\mathrm{y}$, sobre todo, de cuáles pueden tener mayor probabilidad de éxito.

\section{c) Como deber postcontractual}

Una vez finalizado el encargo del cliente, el abogado debe informar el resultado, dando a conocer aquellos detalles que le permitan al primero evaluar el cumplimiento del contrato y tomar decisiones relacionadas al encargo concluido. La entrega de esta información puede resultar trascendental para el éxito de un determinado negocio, por lo cual la negligencia del abogado en el suministro de esta información puede acarrear, eventualmente, su responsabilidad civil, si por su omisión se produce un perjuicio al cliente.

\footnotetext{
${ }^{19}$ De Ángel Yágüez, Ricardo, "Responsabilidad por informar", en Juan Antonio Moreno Martínez, Perfiles de la responsabilidad civil, Madrid, Dykinson, 2000, p. 171.
} 


\section{Requisitos de la información}

La información que debe suministrar el abogado ha de cumplir con un estándar mínimo, el problema es la dificultad de establecer una información tipo de la que debe exigir el cliente. La importancia de definir este estándar radica en que, si la información suministrada no es adecuada, la prestación puede considerarse defectuosa. Por esa razón, será fuente de responsabilidad civil si de ahí derivan consecuencias dañosas para el cliente.

Por lo demás, es necesario que este estándar mínimo se cumpla durante todo el iter contractual, y no solo durante la ejecución del contrato. Expondremos a continuación algunas características para evaluar si la entrega de la información por parte del letrado cumple con dicho estándar mínimo. Asimismo, estas permiten valorar si se ha cumplido con este deber. ${ }^{20}$

\section{a) Información completa}

La información es completa cuando no se omite parte de ella o detalles que pueden resultar relevantes para el cliente. La cuestión pasa entonces por determinar qué información es relevante para el cliente, puesto que el exceso de información, es decir, su entrega exhaustiva, puede resultar notablemente contraproducente. Esto significa confundir al cliente, al impedirle conocer aquellas cuestiones principales que amerita saber según la naturaleza del encargo.

\section{b) Información comprensible}

Nuestra ley de protección al consumidor se refiere a las características que debe reunir la información suministrada por el proveedor. Señala en su artículo primero, último párrafo, que "La información básica comercial deberá ser suministrada al público por medios que aseguren un acceso claro, expedito y oportuno".

Igualmente, la Ley 20.584 que regula los derechos y deberes que tienen las personas en relación con las acciones vinculadas a su atención en salud establece, en su artículos 8 y 10, el deber de información. El artículo 8 señala: "Toda persona tiene derecho a que el prestador institucional le proporcione

\footnotetext{
${ }^{20}$ Maria Dolores, Cervilla Garzón, "La obligación de información del abogado", Revista General de Derecho, núm. 676-677, pp. 94-95. "Por ello, se hace necesario acudir a un criterio que, aplicado a cada prestación de servicios, nos determine cuál es la información debida por el letrado y por la que responderá en caso de incumplimiento (bien por inexistencia, bien por prestación defectuosa). En cualquier caso, serán las exigencias de la buena fe, adaptadas a la relación jurídica concreta que se entabla entre letrado y cliente, las que delimitarán los extremos específicos de la información debida por ese abogado, a ese cliente y en base a esa concreta relación de prestación de servicios."
} 
información suficiente, oportuna, veraz y comprensible, sea en forma visual, verbal o por escrito". Por su parte, el artículo 10 indica: "Toda persona tiene derecho a ser informada, en forma oportuna y comprensible”.

Teniendo en cuenta la disposición referente a la ley de protección al consumidor citada, se debe considerar que el proveedor del bien o servicio debe, por una parte, informar; pero, además, asegurar que pueda acceder el cliente a ella. Por lo tanto, no basta suministrar la información, sino que debe existir certeza de que el cliente la tendrá a su alcance.

Ahora bien, que el cliente haya tenido acceso a la información no significa que la ha comprendido. Esto tiene relevancia, pues el problema que describíamos en la primera parte de este trabajo: la mayoría de las veces existe un problema de racionalidad limitada y de asimetría de información entre abogado y cliente.

La cuestión, luego, pasa por entender que se quiere decir con "asegurar un acceso claro”. En este punto, se puede interpretar que la información es clara cuando puede ser comprendida sin dificultad. Esta exigencia obligaría al abogado a asegurarse de que la información ha sido comprendida por su cliente. Esto es así porque, en la mayoría de los supuestos, el nivel de formación de los clientes puede ser muy disimil; por lo tanto, lo que es claro para uno no lo es para otro. Por lo mismo, esta exigencia obligaría al letrado a adecuar la entrega de la información conforme al tipo de cliente que enfrenta. Así, no es posible suministrar un tipo de información estándar, sin precaver si el receptor de la información está preparado para comprenderla.

Por otro lado, la Ley 20.584 que regula los derechos y deberes que tienen las personas en Chile, en relación con las acciones vinculadas a su atención en salud, es más precisa que la de protección al consumidor, pues establece expresamente que la información entregada debe ser comprensible, además de oportuna.

Si bien las disposiciones de las leyes citadas deberían regir en aquellos ámbitos específicos para los cuales fueron concebidas, es posible que nuestros tribunales apliquen la misma exigencia al abogado fuera de dichos ámbitos, con el propósito de que la entrega de información no sea el cumplimiento de un mero trámite, sino que constituya la finalidad esperada. Esta es que el cliente conozca lo que está contratando, que tenga la debida información de cómo se desarrolla su encargo, cómo ha finalizado este y qué momento de la ejecución del contrato se encuentran las partes.

Lo anterior exige que el abogado adecue la información que debe proporcionar conforme a la preparación y conocimiento del cliente, lo que puede conllevar, por ejemplo, adecuar su lenguaje para que sea asequible al receptor de la información. 
De esta forma, no se cumpliría con este requisito si la información se proporciona condensada en términos técnicos jurídicos de difícil o improbable comprensión para el ciudadano promedio. ${ }^{21}$ De la misma forma, no sería comprensible la información rutinaria que se limita a la mera enumeración de preceptos legales, lo cual únicamente alargaría innecesariamente la información. ${ }^{22}$

En España, la jurisprudencia del Tribunal Supremo ${ }^{23}$ ha exigido al abogado una posición activa. Este debe cerciorarse de que la información no solo ha sido recibida, sino además comprendida por el cliente. Lo importante son los resultados prácticos de la información, pues, de lo contrario, solo existiría un respeto formal de este deber u obligación, lo cual se traduce en aproximar el deber de información a una obligación de resultado. ${ }^{24}$

\section{c) Información veraz}

Si la información que se entrega no es auténtica o contiene elementos incorrectos por falta de precisión, no cumplirá con el estándar exigido y, por ende, no se podrá considerar como verdadera información. Como ya indicamos en el apartado anterior, esta misma exigencia se impone al prestador institucional de salud en relación con la información que debe proporcionar al paciente. Por ello, es lógico que en este ámbito también se pida, pues de lo contrario la información no cumpliría el fin esperado. Además, el incumplimiento de este requisito puede acarrear consecuencias civiles, en el caso de que, por la entrega de información inexacta, se produzca un daño.

\section{d) Información oportuna}

La información debe ser entregada al cliente cada vez que sea necesario, conforme a la necesidad del momento. Esto es así debido a que la información tiene utilidad según el minuto en que se proporciona, por tanto, no es baladí el tema de la oportunidad como requisito de la información. Cabe este deber de informar desde un primer momento, desde antes de que se celebre el contrato, para que, de este modo, el cliente pueda emitir un consentimiento informado.

\footnotetext{
${ }^{21}$ Kraut, Alfredo Jorge, "Información: un derecho constitutivo del hombre en sociedad. Algunos enfoques jurídicos", Derecho de daños. Segunda parte, Buenos Aires, La Rocca, 2000, p. 606.

${ }^{22}$ Crespo Mora, Maria Carmen, La responsabilidad del abogado en el derecho civil, Madrid, Civitas, 2005, p. 166.

${ }^{23}$ En España una de las primeras sentencias del Tribunal Supremo que hace referencia a esta obligación de informar es la del 14 de mayo de 1999 (STS № 431/1999), por el incumplimiento del abogado de entregar la debida información a sus clientes, respecto de un auto de archivo que impedia seguir persiguiendo las responsabilidades penales por la muerte de un hijo en una piscina.

${ }^{24}$ Crespo Mora, Maria Carmen, La responsabilidad del abogado en el derecho civil, Madrid, Civitas, 2005, p. 166.
} 
También será necesario informar durante la ejecución del contrato, y una vez finalizado el mismo. En definitiva, la oportunidad de la información deberá ser valorada caso a caso, según las circunstancias y necesidades, de modo que no es posible establecer un repertorio casuístico. ${ }^{25}$

\section{Responsabilidad por el incumplimiento del deber de informar}

Como ya se ha indicado, el deber de informar del abogado emana de los principios generales de la contratación, sin que exista hasta ahora norma legal expresa que lo exija, como sí sucede en el ámbito de las prestaciones médicas. No obstante, el deber de informar del abogado podría encontrar eventualmente su fundamento en la ley de protección al consumidor, si es que se cumplen los presupuestos establecidos por dicha ley. Además, sabemos que se distinguen tres momentos en que le asiste al abogado el deber de informar: antes de la celebración del contrato, durante la ejecución y en ciertas oportunidades, luego de finalizado el encargo.

\section{a) Distinción entre obligación de medios o de resultados}

En la fase contractual, es relevante determinar si durante la ejecución del contrato el deber de informar es una obligación de medios o de resultados. Así, para efectos de definir el régimen de responsabilidad aplicable, la hipótesis de responsabilidad será por culpa, en el primer caso, y objetiva, en el segundo. ${ }^{26}$

Comprender el deber de informar del abogado como una obligación de medios significa determinar si se desplegó un comportamiento conducente a informar al cliente, conforme a un estándar de conducta previsto en la ley, en caso de aplicación de la ley sobre protección de los derechos de los consumidores o conforme a la lex artis del profesional. Si existe un desajuste entre el

${ }^{25}$ Crespo Mora señala que la información ha de ser continuada y que deberá extenderse a lo largo de toda la relación contractual. Crespo Mora, Maria Carmen, La responsabilidad del abogado en el derecho civil, Madrid, Civitas, 2005, p. 167.

${ }^{26}$ En términos amplios se han referido a este tema Peñalillo Arévalo, Daniel, Obligaciones. Teoría general y clasificaciones. La resolución por incumplimiento, Santiago, Editorial Jurídica de Chile, 2003, pp. 338 y SS; Barros BouriE, EnRIoue, Tratado de responsabilidad extracontractual, Santiago, Editorial Jurídica de Chile, 2006, p. 662; TAPIA Rodriguez, MAuRicio, "Responsabilidad civil médica: riesgo terapéutico, perjuicio de nacer y otros problemas actuales", Revista de Derecho de Valdivia, vol. 15, p. 75; PIzArRo Wilson, Carlos, "La culpa como elemento constitutivo del incumplimiento en las obligaciones de medio o de diligencia", Revista de Derecho de la Pontificia Universidad Católica de Valparaiso, vol. 31, p. 255, y Dominguez Hidalgo, CARmen, "El problema de la culpa presunta contractual y las obligaciones de medio y obligaciones de resultado: sus implicancias para la responsabilidad médica", en Iñigo de la Maza Gazmuri (comp.), Cuadernos de análisis jurídico, Santiago, Universidad Diego Portales, 2010, pp. 21 y ss. 
actuar y la ejecución que se espera, existirá culpa; por ende, si hubiere daño, se desencadena la responsabilidad.

Para perseguir la responsabilidad, el cliente -como acreedor-deberá acreditar la relación contractual con el letrado y el incumplimiento que alega. Conforme al artículo 1547 inciso 3 del Código Civil chileno, el abogado -como deudor- deberá desplegar el esfuerzo probatorio para acreditar que se ajustó a la lex artis o que cumplió el deber impuesto por la ley, si cabe el caso. Esto último es así debido a que, conforme al artículo 1698 del Código Civil chileno, quien debe probar la extinción de la obligación es quien la alega. ${ }^{27}$

En cambio, si se califica el deber de informar como una obligación de resultado, debería considerarse que la responsabilidad es objetiva. En este supuesto, ya no importa si el comportamiento del abogado era el esperado o no; solo es necesario que se verifique la infracción a este deber y el daño. Ya no es el comportamiento el que se analiza, no importa si el letrado cumplió su deber conforme al modelo esperado para determinar si existió negligencia, sino que basta el acto. Así, lo que se señala es la omisión de informar conforme al estándar esperado, así como el daño, para que exista responsabilidad.

Determinar si la obligación de informar es de medios o de resultado pasa, en gran parte, por saber si al abogado se le impone el deber de informar una vez se ha asegurado de que el cliente ha recibido y comprendido la información. Si no se le exige esto último, la obligación será de medios, en cambio, si se le pide lo primero, será de resultado. Ello bajo el supuesto de que el deber de información se enmarca como una prestación accesoria y no principal.

En caso de que la información que debe entregar el abogado sea una obligación principal, cabe preguntarse si esta sería de medio o de resultado. Por ejemplo, cuando un abogado se obliga a entregar un informe en derecho; normalmente, este tipo de trabajo se solicita a los letrados con el propósito de ilustrar acerca de un determinado problema jurídico y, según sea el caso, influir a través de este a un tribunal o autoridad administrativa para que se pronuncie de un determinado modo.

En este caso, el fin último del informe es ilustrar y enseñar el derecho con el fin de esclarecer una determinada cuestión, no se obliga el abogado a influir en la decisión de un tercero. Por lo tanto, la prestación se cumple con la entrega del informe, que obviamente debe reunir las características propias que este tipo de trabajo exige, y con el esclarecimiento del conflicto jurídico existente. En este sentido, la obligación es de resultado, pues el abogado se compromete

${ }^{27}$ Pizarro Wilson, Carlos, "La culpa como elemento constitutivo del incumplimiento en las obligaciones de medio o de diligencia", Revista de Derecho de la Pontificia Universidad Católica de Valparaíso, vol. 31, pp. 255 y ss. 
a entregar un trabajo con características determinadas para arrojar ciertas conclusiones, a modo de que el cliente pueda tomar una decisión.

De este modo, la obligación de informar durante la ejecución del contrato podrá ser de medios si es una prestación accesoria, bajo el entendido de que al letrado no se le exija que el cliente comprenda la información entregada; de lo contrario, esta obligación será de resultado. Esto último sucede normalmente cuando el objeto principal del encargo es defender los intereses del cliente en juicio.

A nuestro parecer, el abogado cumple con la obligación de información si esta reúne las condiciones necesarias que se han enunciado en este trabajo: que sea completa, comprensible, veraz y oportuna. En el caso de que la prestación sea principal, es decir, que no asume la defensa de los intereses en un juicio, sino que se comprometa a entregar un informe en derecho, la obligación será de resultado, ya que su asesoramiento debe cumplir con entregar luces sobre un determinado problema. Sea acertado o no, el consejo o asesoramiento es a lo que se obliga el abogado, y esto se cumple con la entrega de un informe o dictamen. Por lo tanto, su obligación es de resultado, es decir, la entrega del trabajo contratado.

\section{b) Consecuencias del incumplimiento del deber de informar}

Las consecuencias del incumplimiento pueden ser diversas, dependiendo de si la infracción de este deber es motivo suficiente para alegar la nulidad del contrato por vicios en el consentimiento o no. Es claro que, si el abogado indujo a su contraparte a celebrar el contrato bajo error, es posible demandar la nulidad del contrato, pues la voluntad del cliente no cumple con los requisitos para que esta produzca plenos efectos. ${ }^{28}$

Si no se cumple con lo anterior, para determinar las consecuencias del incumplimiento, debemos nuevamente distinguir si la obligación de informar es una prestación accesoria o principal. Esto es así porque la relación entre abogado y cliente es de carácter sinalagmático, es decir las partes son a la vez acreedoras y deudoras de prestaciones recíprocas. Por lo tanto, si la prestación de informar del abogado es accesoria, no es posible que el cliente oponga la exceptio non adimpleti contractus ante la reclamación del pago de honorarios debido. En este caso, sería la obligación principal del cliente, pues su alegación sería contraria a la buena fe, requisito fundamental para ejercitar el referido medio de defensa.

\footnotetext{
${ }^{28}$ Los artículos 1453 a 1455 de nuestro Código Civil regulan los tipos de errores y sus efectos.
} 
Ahora bien, para el correcto ejercicio de la excepción del contrato no cumplido, lo importante es determinar si el incumplimiento de la prestación accesoria puede devenir en importantes consecuencias para el acreedor. Si esto es así, incluso podría oponerse la excepción del contrato no cumplido por el incumplimiento de una obligación accesoria que es fundamental para el interés del acreedor y, en consecuencia, para la correcta ejecución del contrato.

La cuestión es mucho más clara si el abogado incumple el deber de informar cuando esta obligación es la prestación principal del contrato. En tal caso, el cliente podrá oponer la excepción de contrato no cumplido ante la demanda de cumplimiento del abogado.

También será posible demandar la resolución del contrato conforme al artículo 1489 del Código Civil chileno, si el incumplimiento reviste las características suficientes que ameriten la ruptura del vínculo contractual. Solicitar el cumplimiento del contrato puede llegar a ser una opción, sin embargo, creemos que en la mayoría de los casos se debe descartar, puesto que, en este contexto, el cumplimiento resultará casi siempre imposible.

Con base en la jurisprudencia española que existe en este ámbito, es posible percatarnos de que, en la práctica, los casos relacionados con el incumplimiento de este deber frecuentemente se deben a negligencias relacionadas con dejar transcurrir un plazo. Con la consecuente prescripción de la acción o la caducidad de un determinado recurso legal, no es posible exigir el cumplimiento de la prestación ante la imposibilidad de seguir adelante con el pleito.

Por otra parte, el cliente tiene la posibilidad de reclamar la correspondiente indemnización de perjuicios cuando, por el incumplimiento del deber de información, se ocasiona un daño. En este caso, ya no es relevante determinar si la prestación es principal o accesoria, sino establecer la existencia del daño, y si concurren los demás requisitos de la responsabilidad civil. ${ }^{29}$

\section{Conclusiones}

A diferencia de lo que ocurre en el ámbito de la responsabilidad médica, el abogado no tiene la obligación legal de suministrar información a su cliente. Por tanto, la regulación de este deber queda entregada a las reglas del derecho común, a las normas profesionales (lex artis) y, excepcionalmente, a la ley de protección del consumidor.

\footnotetext{
${ }^{29}$ Cabe destacar las caracteristicas que tiene este tipo de daño, especialmente la pérdida de una oportunidad y su determinación cuando el abogado incumple el deber de información. Estas fueron abordadas en un primer trabajo, que trata la responsabilidad del abogado en relación con el deber precontractual de informar.
} 
Durante la ejecución del contrato, es posible encontrar el fundamento del deber de información en las reglas del mandato, en especial en el artículo 2155, el cual obliga al mandatario a dar cuenta de su administración. También se puede justificar en el artículo 1546 del Código Civil, que obliga a las partes a ejecutar el contrato de buena fe. Excepcionalmente, se puede justificar en la ley de protección al consumidor, si el abogado es considerado proveedor y el cliente, consumidor.

En términos generales, se distinguen tres oportunidades en que el abogado debe informar a su cliente: durante el proceso de formación del consentimiento, durante la ejecución del contrato y una vez finalizado el encargo dado al letrado.

Se cumple con el deber de información si se reúnen ciertos requisitos. Es decir, que la información sea completa, comprensible, veraz y oportuna. En caso de incumplimiento del deber de informar, el cliente podrá demandar la nulidad del contrato por vicios en el consentimiento; ejercitar la excepción de incumplimiento contractual, o pedir la resolución del contrato. Asimismo, podrá perseguir la indemnización de daños cuando concurran los demás presupuestos de la responsabilidad civil. 